\title{
KINERJA PEGAWAI MENJELANG MASA PURNABAKTI : PERAN BUDAYA KERJA, KEMAMPUAN KERJA, DAN KOMITMEN ORGANISASI (Studi Pada Lingkup Kanwil Ditjen Perbendaharaan Provinsi D. I. Yogyakarta)
}

\author{
Sugeng Widodo ${ }^{1}$ \\ Abdul Choliq Hidayat ${ }^{2}$ \\ Aftoni Sutanto ${ }^{3}$ \\ ${ }^{1}$ Universitas Ahmad Dahlan Yogyakarta \\ Email : sugengwidodo2010@gmail.com \\ ${ }^{2}$ Universitas Ahmad Dahlan Yogyakarta \\ Email : hacholiqh@gmail.com \\ ${ }^{3}$ Universitas Ahmad Dahlan Yogyakarta \\ Email : aftoni.sutanto@mm.uad.ac.id
}

\begin{abstract}
Employee performance is a discussion that has never been bored to be examined from various points of view. This time the author tries to present employee performance when faced with conditions at the end of the productive age (before retirement). This research provides an understanding of how employees actually ahead of their retirement, how to work culture and the ability whether they still have maximum enthusiasm. More specifically the purpose of this study to test Employee performance is a discussion that has never been bored to be examined from various points of view. This time the author tries to present employee performance when faced with conditions at the end of the productive age (before retirement). This research provides an understanding of how employees actually ahead of their retirement, how to work culture and the ability whether they still have maximum enthusiasm. More specifically the purpose of this study to test: (1) The influence of work culture on employee performance before retirement at the Regional Office of the Directorate General of Treasury, D. I. Yogyakarta Province; (2) The effect of work ability on employee performance prior to retirement at the Regional Office of the Directorate General of Treasury, D. I. Yogyakarta Province; (3) The influence of organizational commitment on employee performance prior to retirement at the Regional Office of the Directorate General of Treasury, D. I. Yogyakarta Province; and (4) The influence of work culture, work ability, and organizational commitment to employee performance prior to retirement at the Regional Office of the Directorate General of Treasury, D. I. Yogyakarta Province. This type of research used in this research was quantitative. The population in this study were all employees of the Regional Office of the Directorate General of Treasury of the Province D. I. Yogyakarta who will enter their retirement period within the next 5 (five) years starting from 2020 to 2025 totaling 60 employees. The sampling technique in this study was a census or total sample, namely the entire sample of 60 employees. The data collection technique used a questionnaire. The data analysis technique used multiple linear regression analysis. Based on the results of the research that has been done, the following conclusions are obtained: (1) Work culture has a positive and significant effect on employee performance before retirement in the Regional Office of the Directorate General of Provincial Treasury In Yogyakarta. (2) Job ability has a positive and significant effect on employee performance prior to retirement at the Regional Office of the Directorate General of Treasury, Province D. I. Yogyakarta. (3) Organizational commitment has a positive and significant effect on employee performance before retirement at the Regional Office of the Directorate General of Treasury, Province D. I. Yogyakarta. (4) Work culture, work ability, and organizational commitment have a positive and significant effect together on employee performance prior to retirement at the Regional Office of the Directorate General of Treasury, D. I. Yogyakarta Province.
\end{abstract}

Keywords: work culture, work ability, organizational commitment, employee performance.

\section{PENDAHULUAN}

Sebagai salah satu organisasi, Instansi pemerintah berkewajiban untuk mengoptimalkan dan meningkatkan kinerja pegawainya. Akan tetapi, pandemi Covid-19 yang masih dialami Indonesia tentu mempengaruhi kinerja para Pegawai Negeri Sipil. Hal ini disebabkan adanya himbuan pemerintah untuk bekerja dari rumah. Kebijakan yang mengatur Penyesuaian Sistem Kerja Aparatur Sipil Negara dalam Upaya Pencegahan Covid-19 di Lingkungan Instansi Pemerintah terdapat pada Surat Edaran 
Menteri Pendayagunaan Aparatur Negara dan Reformasi Birokrasi Nomor 19 Tahun 2020. Yudho Winarto (2020) menjelaskan, instrumen tersebut difungsikan sebagai pedoman Work From Home (WFH) bagi Aparatur Sipil Negara sebagai langkah meminimalisir penyebaran Covid-19. Sehingga tujuan Surat Edaran tersebut, diantaranya: (1) Upaya mencegah serta meminimalisir resiko dan penyebaran Covid-19 pada lingkungan Instansi Pemerintah maupun masyarakat; (2) Pencapaian kinerja di masing-masing unit dapat berjalan dengan baik dan tetap terjaga sesuai dengan tugas pokok dan fungsinya; dan (3) Instansi Pemerintah tetap mampu memberikan layanan secara optimal.

Mengingat kondisi tersebut, maka pemerintah harus berupaya agar para pegawai di berbagai instansinya tetap bekerja secara optimal, sehingga kinerja pegawai juga tetap optimal. Oleh karena itu, pemerintah perlu memperhatikan berbagai faktor yang dapat mempengaruhi kinerja pegawai, terutama yang akan mengalami masa purnabakti. Faktor apa saja yang mampu dioptimalkan oleh Instansi untuk tetap mempertahankan semangat kerja yang optimal bagi karyawan yang memasuki masa purnabakti. Salah satu faktor yang dapat mempengaruhi kinerja pegawai adalah budaya kerja. Susanto (2000) menjelaskan, dalam mengurai permasalahan dari luar serta menyesuaikan integrasi dengan perusahaan sumber daya manusia membutuhkan suatu pedoman, hingga setiap anggota organisasi dapat mengenal nilai-nilai serta perilaku yang seharusnya mereka perlihatkan, nilai tersebut dikenal sebagai budaya kerja. Sependapat dengan hal tersebut, Silvia, dkk (2016: 2) juga menegaskan kinerja baik pegawai akan terjadi selama budaya kerja berjalan baik pada organisasi tersebut. Penelitian Hasdiah, dkk (2018) membuktikan bahwa budaya kerja juga berpengaruh signifikan terhadap kinerja pegawai.

Berpijak pada hal tersebut maka setiap instansi pemerintah diharapkan dapat menciptakan budaya kerja yang aman bagi pegawai agar mereka terhindar dari penularan Covid-19. Oleh karena itu, protokol kesehatan harus menjadi budaya kerja yang harus dilaksanakan oleh setiap instansi. Para Aparatur Sipil Negara diwajibkan mematuhi serangkain prosedur protokol kesehatan sebelum memasuki tempat kerja seperti mencuci tangan, pengecekan suhu tubuh, memakai masker hingga menjaga jarak fisik. Perlunya regulasi khusus bagi Aparatur Sipil Negara dalam fleksibilitas bekerja, seperti penerapan lokasi kerja Work From Office (WFO) atau Work From Home (WFH), yang dinilai menjadi langkah tepat dalam beradaptasi dengan kondisi pandemi yang sedang terjadi. Pemberlakuan WFO/WFH memunculkan konsekuensi tuntutan kerja menggunakan teknologi informasi yang mengakibatkan pertanyaan apakah kinerja pegawai yang memasuki purnabakti masih maksimal.

Dalam penyesuaian dengan tatanan normal baru, Pejabat Pembina Kepegawaian diharapkan menyiapkan segala sarana dan prasarana guna mendukung sistem kerja baru bagi Apatur Sipil Negara, sehingga pemerintahan serta pelayanan publik tetap terlaksana dengan baik, Hal lainnya perlu juga mempertimbangkan keandalan teknologi informasi serta keamanan sdata. Panduan Pencegahan dan Pengendalian Covid-19 di Tempat Kerja Perkantoran dan Industri dalam Mendukung Keberlangsungan Usaha pada Situasi Pandemi yang tercantum dalam Keputusan Menteri Kesehatan Nomor HK.01.07/MENKES/328/2020, juga menjadi landasan bagi Pejabat Pembina Kepegawaian untuk menyelaraskan fleksibilitas kerja guna menekan penyebaran Covid-19. Status penyebaran Covid-19 yang dikeluarkan Gugus Tugas Percepatan Penangangan Covid-19, menjadi landasan penyelenggaraan sistem kerja baru untuk Aparatur Sipil Negara. Masing-masing Pejabat Pembina Kepegawaian mengambil peran perihal penyesuaian sistem kerja Aparatur Sipil Negara. Setiap unit organisasi dibawah Pejabat Pembina Kepegawaian akan selalu dipantau penyelenggaraannya sesuai dengan Surat Edaran Menteri Pendayagunaan Aparatur Negara dan Reformasi Birokrasi Nomor 58/2020. Pimpinan instansi, menurut Surat Edaran ini melakukan evaluasi atas efektivitas pelaksanaan Surat Edaran tersebut dan melaporkannya kepada Menteri Pendayagunaan Aparatur Negara dan Reformasi Birokrasi.

Selain budaya kerja, kinerja pegawai juga dipengaruhi oleh kemampuan kerja (Sunjaya, dkk, 2017: 1). Hal ini dapat dipahami mengingat kemampuan kerja merupakan kapasitas individu untuk melakukan beragam tugas dalam suatu pekerjaan. Kemampuan mencerminkan sebuah penilaian terkini atas apa yang dapat dilakukan seseorang (Robbins dan Judge, 2008). Hasil penelitian Jatiningrum, dkk (2016) membuktikan bahwa kemampuan kerja berpengaruh terhadap kinerja karyawan. Ditengah kondisi WFH yang mengandalkan teknologi informasi maka diperlukan peningkatan kemampuan kerja pegawai dalam penguasaan teknologi informasi, ini menjadi rentan karena rata-rata adalah pegawai yang mendekati purnabakti yang agak lemah dalam penguasaan teknologi. Oleh karena itu, budaya kerja dan peningkatan kemampuankerja pegawai dalam hal teknologi informasi merupakan hal yang penting ketika dihadapkan pada upaya peningkatan kinerja organisasi dan pegawai di dalamnya (Putranti, dkk, 2018: 192). 
Kinerja pegawai juga dapat dipengaruhi oleh komitmen organsiasi. Dalam pandangan Robbins (2006: 69), kondisi seorang pegawai yang mengerahkan untuk berpihak pada organisasi serta tujuannya, juga menjaga keanggotaanya, dinamakan komitmen organisasi. Tingginya individu saat terlibat menandakan keterpihakannya pada pekerjaan, sedang tingginya komitmen organisasi menandakan keberpihakan pada organisasi yang memberi individu sebuah pekerjaan. Senada dengan hal tersebut, Mathnis dan Jackson (2011: 122) menyampaikan, organisasi mampu mengawasi keandalan pegawai dalam menjalankan tugasnya, melalui komitmen pegawai. Pegawai yang menjunjung komitmen pegawai, akan melaksanakan upaya guna memprioritaskan pekerjaan serta organisasi sehingga mampu mencapai tujuannya. Lama menetapnya pegawai dalam organisasi, dapat dilihat melalui kuatnya komitmen yang dimiliki (Nasution, 2017). Hasil penelitian menunjukkan oleh Muis, dkk, (2018) membuktikan bahwa ada pengaruh positif dan signifikan komitmen organisasi terhadap kinerja karyawan.

Penelitian ini mengambil obyek semua pegawai yang akan memasuki masa purnabakti pada lingkup Kantor Wilayah Direktorat Jenderal Perbendaharaan Provinsi D. I. Yogyakarta. Kantor Wilayah Direktorat Jenderal Perbendaharaan Provinsi D. I. Yogyakarta merupakan Unit Vertikal dibawah Kementerian Keuangan RI, yang dipimpin oleh seorang Kepala Kantor Wilayah, yang bertanggung jawab kepada Direktur Jenderal Perbendaharaan Kementerian Keuangan. Letak Kantor Wilayah Direktorat Jenderal Perbendaharaan Provinsi D. I. Yogyakarta berada di Jl. Solo KM 8,6 Nayan, Depok, Maguwoharjo, Sleman.

Kantor Wilayah Direktorat Jenderal Perbendaharaan Provinsi D. I. Yogyakarta selalu berupaya untuk meningkatkan kinerja pegawainya. Upaya meningkatkan kinerja pegawai dilakukan salah satunya dengan melaksanakan program budaya kerja sesuai dengan nilai-nilai Kementerian Keuangan, yaitu Integritas, Profesionalisme, Sinergi, Pelayanan dan Kesempurnaan. Dalam upaya meningkatkan kinerja dimaksud, diperlukan upaya ektrsa agar tujuan organisasi dapat tercapai, mengingat sebagian besar pegawai akan memasuki masa purnabakti.

Masa purnabakti pasti akan dialami setiap pegawai, namun tak jarang muncul kecemasan hingga menganggu capaian kinerja. Disamping pendapatan yang berkurang, hal lain yang menjadi perhatian adalah kepribadian pegawai. Mereka tidak lagi disibukkan dengan aktivitas harian seperti biasa sehingga menghilang dari aktivitas kerja. Usia yang tidak lagi produktif membawa kebingungan pada sejumlah pegawai. Diperlukan pendekatan secara psikologis untuk meningkatkan motivasi guna tetap meyakinkan pegawai untuk menjaga kinerjanya.

Banyaknya pegawai yang akan memasuki masa purnabakti pada lingkup Kantor Wilayah Direktorat Jenderal Perbendaharaan, dalam kurun waktu lima tahun terhitung mulai tahun 2020 sampai dengan 2025 terdapat 60 pegawai yang akan memasuki masa purnabakti. Hal ini menjadi tantangan yang menarik dalam hal meningkatkan dan mempertahankan kinerja pegawai untuk mencapai tujuan organisasi.

Menjadi hal yang sangat menarik, bahwa pegawai yang memasuki masa purnabakti ternyata memiliki kinerja yang baik. Meskipun hampir sebagian besar pegawai memasuki masa purnabakti atau pensiun namun pada kenyataannya dapat berpengaruh positif terhadap peningkatan kinerja di Kantor Wilayah Direktorat Jenderal Perbendaharaan Provinsi D. I Yogyakarta. Terbukti dengan diraihnya penghargaan terbaik selama lima tahun berturut-turut sejak tahun 2015 sebagai pengelola kinerja terbaik eselon I Kementerian Keuangan pada lingkup Direktorat Jenderal Perbendaharaan Kementerian Keuangan.

Hasil Penilaian Kinerja Pegawai Lingkup Kanwil Ditjen Perbendaharaan Provinsi D. I. Yogyakarta kurun waktu tahun 2015 - 2019 menunjukkan Nilai Prestasi Kinerja Pegawai (NPKP) sangat baik yang dihitung berdasarkan Keputusan Menteri Keuangan Republik Indonesia Nomor 467/KMK.01/2014 tanggal 1 Oktober 2014 tentang Pengelolaan Kinerja di Lingkungan Kementerian Keuangan. Akan tetapi, saat ini wabah Covid-19 juga berdampak pada pegawai yang hampir memasuki punabakti di Kantor Wilayah Direktorat Jenderal Perbendaharaan Provinsi D. I. Yogyakarta. Banyak dari mereka ternyata mampu menyesuaikan diri dengan sistem kerja di masa adaptasi kebiasaan baru misalnya dalam menggunakan teknologi berbasis Teknologi Informasi untuk bekerja dari rumah. Kondisi tersebut tentu mempengaruhi kinerja pegawai. Berpijak pada kondisi tersebut, maka peneliti tertarik untuk mengkaji secara lebih mendalam tentang "Pengaruh Budaya Kerja, Kemampuan Kerja, dan Komitmen Organisasi terhadap Kinerja Pegawai Menjelang Masa Purnabakti pada Lingkup Kantor Wilayah Direktorat Jenderal Perbendaharaan Provinsi D. I. Yogyakarta". 


\section{KAJIAN PUSTAKA Kinerja}

Menurut Hasibuan (2012: 64) mengartikan kinerja adalah hasil kerja yang dicapai seseorang dalam melaksanakan tugas-tugas yang dibebankan kepadanya, berdasarkan kecakapan, pengalaman, kesungguhan dan waktu. Sedang As'ad (2001: 63) berpendapat bahwa kinerja adalah suatu kesuksesan seseorang dalam melaksanakan suatu pekerjaan. Faktor lain yang mempengaruhi kinerja, diantaranya: (1) Faktor internal pegawai, yakni karakter yang dibawa oleh pegawai, seperti keandalan, kejiwaan, hingga motivasi kerja; (2) Faktor lingkungan internal organisasi, yakni support organisasi terhadap pegawai, seperti kebijakan organisasi, sistem manajemen hingga kompensasi; dan (3) Faktor lingkungan eksternal organisasi, yakni pengaruh kinerja pegawai dari kondisi di luar lingkup organisasi, seperti kehidupan politik dan kompetitor (Wirawan, 2009: 7-8).

Terdapat pula enam indikator dari kinerja, diantaranya: (1) Kualitas kerja yakni ketelitian, akurasi serta posentase diterimanya hasil kerja; (2) Produktivitas yakni jumlah serta optimalsasi pekerjaan dalam kurun waktu tertentu; (3) Pengetahuan mengenai pekerjaan yakni keandalan praktis dan wawasan perihal pekerjaan; (4) Kepercayaan yakni ukuran keandalan karyawan dapat menuntaskan pekerjaan hingga tahap selanjutnya; (5) Ketersediaan yakni penjadwalan optimal karyawan saat perada dalam lingkup pekerjaan; dan (6) Kebebasan yakni tolok ukur karyawan mampu menuntaskan pekerjaan tanpa pendampingan (Dessler, 2010: 329).

\section{Budaya Kerja}

Budaya kerja datang dari gagasan filosofis, yang kemudian mendapat implementasi secara formal pada lingkup karyawan berdasarkan kebijakan perusahaan (Moeljono, 2005). Budaya kerja dapat didefinisikan sebagai satu buah sistem yang mencakup nilai, norma dan kepercayaan pada organisasi yang menjadi arahan anggota dalam mengatasi masalah adaptasi eksternal dan integrasi internal (Mangkunegara, 2005). Robbins (2006) menjelaskan, dalam budaya kerja terdapat indikator serta dimensi, antara lain: (1) Inovasi dan mengambil resiko; (2) Perhatian pada rincian; (3) Orientasi hasil; (4) Orientasi manusia; (5) Orientasi tim; (6) Agresifitas; dan (7) Stabilitas yakni kondisi organisasi yang senantiasa dipertahankan.

\section{Kemampuan Kerja}

Robbins (2006: 49) menjelaskan, individu dengan kecakapan mental dan fisik menandakan kemampuan kerja yang dimiliki, karena adanya keterkaitan diantara keduanya, yang nantinya berpengaruh terhadap kinerja kerja. Dalam pandangan lain Thoha (2002:154) mendifinisikan kemampuan pegawai: "Kemampuan adalah suatu kondisi yang menunjukkan unsur kematangan yang berkaitan pula dengan pengetahuan dan ketrampilan yang dapat diperoleh melalui pendidikan, latihan dan pengetahuan".

Kemampuan kerja juga diklasifikasikan oleh Rao (2000:98) dalam empat bagian, antara lain: (1) Kemampuan teknis, meliputi pemahaman terhadap bidang khusus yang bersifat teknis hingga procedural; (2) Kemampuan perilaku, meliputi kecakapan dalam menjalin sosial kepada orang lain; (3) Kemampuan manajerial, meliputi monitoring, organizing, planning, valuating dan sebagainya; dan (4) Kemampuan konseptual, meliputi kecakapan dalam memahami sebuah organisasi dengan utuh.

\section{Komitmen Organisasi}

Robbins dan Judge (2006:100) mendefinisikan komitmen sebagai suatu keadaan dimana seorang individu memihak organisasi serta tujuan-tujuan dan keinginannya untuk mempertahankan keangotaannya dalam organisasi. Mathis dan Jackson (2011: 155) mendefinisikan komitmen organisasi dengan kondisi pegawai memahami tujuan organisasi serta menetapkan loyal terhadap organisasi.

Robbins (2006: 101) mengemukakan komitmen organisasi memiliki 3 indikator: (1) Komitmen Afektif (Affective Commitment), yakni menempatkan empati serta mempercayai nilai yang dianut organisasi; (2) Komitmen Berkelanjutan (Continuance Commitment), yakni poin ekonomis yang didapatkan pegawai dengan menetap dan loyal terhadap organisasi; (3) Komitmen Normatif (Normative Commitment), yakni alasan moral seorang pegawai untuk bertahan dan berkontribusi dalam kemajuan organisasi. 


\section{METODE PENELITIAN}

Jenis penelitian yang digunakan dalam penelitian ini adalah kuantitatif. Populasi dalam penelitian ini adalah seluruh pegawai lingkup Kanwil Ditjen Perbendaharaan Provinsi D. I. Yogyakarta yang akan memasuki masa purnabakti dalam kurun waktu 5 (lima) tahun mendatang terhitung mulai tahun 2020 sampai dengan tahun 2025 sejumlah 60 pegawai. Teknik pengambilan sampel dalam penelitian ini adalah sensus atau sampel total yaitu seluruh sampel sebanyak 60 pegawai. Teknik pengumpulan data menggunakan kuesioner. Teknik analisis data menggunakan analisis regresi linear berganda.

\section{HASIL DAN PEMBAHASAN}

\section{Hasil Uji Asumsi Klasik}

Uji asumsi klasik yang digunakan dalam penelitian ini meliputi uji normalitas, uji multikolinearitas dan uji linearitas. Uji normalitas digunakan untuk mengetahui apakah model regresi berdistribusi normal atau tidak, uji ini menggunakan pengujian univariate dengan One Sampel Kolmogorov Smirnov. Adapun hasli pengujian normalitas dapat dilihat pada tabel dibawah ini:

Tabel 1. Hasil Uji Normalitas

\begin{tabular}{|l|c|c|c|}
\hline \multicolumn{1}{|c|}{ Variabel } & Z & sig & Keterangan \\
\hline Budaya organisasi $\left(\mathrm{X}_{1}\right)$ & 0,575 & 0,896 & Normal \\
\hline Kemampuan kerja $\left(\mathrm{X}_{2}\right)$ & 0,649 & 0,793 & Normal \\
\hline Komitmen organisasi $\left(\mathrm{X}_{3}\right)$ & 0,590 & 0,878 & Normal \\
\hline Kinerja pegawai $(\mathrm{Y})$ & 0,639 & 0,809 & Normal \\
\hline
\end{tabular}

Sumber : Data primer diolah, 2021

Berdasarkan tabel 1. di atas nilai sig untuk semua variabel lebih besar 0,05 artinya data budaya kerja, kemampuan kerja, komitmen organisasi dan kinerja pegawai berdistribusi normal. Analisis terhadap problem multikolinearitas dilakukan dengan melihat nilai Variante Inflation Factor (VIF), jika nilai VIF yang diamati > 10 maka diduga terjadi problem multikolinearitas.

Tabel 2. Hasil Uji Multikolinearitas

\begin{tabular}{|l|c|c|}
\hline \multicolumn{1}{|c|}{ Variabel } & VIF & Keterangan \\
\hline Budaya organisasi $\left(\mathrm{X}_{1}\right)$ & 1,448 & Tidak ada multikolinearitas \\
\hline Kemampuan kerja $\left(\mathrm{X}_{2}\right)$ & 1,882 & Tidak ada multikolinearitas \\
\hline Komitmen organisasi $\left(\mathrm{X}_{3}\right)$ & 1,940 & Tidak ada multikolinearitas \\
\hline
\end{tabular}

Sumber : Data primer diolah, 2021

Berdasarkan table 2. di atas bahwa semua variabel independen yaitu budaya kerja, kemampuan kerja dan komitmen organisasi memiliki nilai VIF < 10, sehingga dapat disimpulkan bahwa regresi tidak terjadi gejala multikolinearitas. Pedoman yang digunakan untuk menguji linieritas garis regresi dilakukan dengan jalan menguji signifikansi nilai F. Adapun hasil uji linieritas hubungan dapat dilihat pada tabel berikut ini:

Tabel 3. Hasil Uji Linearitas

\begin{tabular}{|c|l|c|c|c|}
\hline No & \multicolumn{1}{|c|}{ Hubungan } & $\mathrm{F}$ & $\mathrm{p}$ & Keterangan \\
\hline 1 & $\begin{array}{l}\text { Budaya organisasi }\left(\mathrm{X}_{1}\right) \text { dan } \\
\text { kinerja pegawai }(\mathrm{Y})\end{array}$ & 0,849 & 0,673 & Linear \\
\hline 2 & $\begin{array}{l}\text { Kemampuan kerja }\left(\mathrm{X}_{2}\right) \text { dan } \\
\text { kinerja pegawai (Y) }\end{array}$ & 1,456 & 0,196 & Linear \\
\hline 3 & $\begin{array}{l}\text { Komitmen organisasi }\left(\mathrm{X}_{3}\right) \text { dan } \\
\text { kinerja pegawai }(\mathrm{Y})\end{array}$ & 0,559 & 0,932 & Linear \\
\hline
\end{tabular}

Sumber : Data primer diolah, 2021

Uji linearitas dilakukan untuk mengetahui apakah variabel yang dianalisis korelasinya mempunyai hubungan linear. Berdasarkan hasil uji linearitas diperoleh hasil sebagai berikut:

a. Ada hubungan yang linear antara variabel budaya organisasi dengan kinerja pegawai dengan nilai $F$ sebesar 0,849 dan $p=0,673(p>0,05)$. 
b. Ada hubungan yang linear antara variabel kemampuan kerja dengan kinerja pegawai dengan nilai $F$ sebesar 1,456 dan $p=0,196(p>0,05)$.

c. Ada hubungan yang linear antara variabel komitmen organisasi dengan kinerja pegawai dengan nilai $F$ sebesar 0,559 dan $\mathrm{p}=0,932(\mathrm{p}>0,05)$.

\section{Hasil Uji Hipotesis}

Uji hipotesis yang digunakan dalam penelitian ini adalah analisisi regresi linear berganda. Hasil perhitungan regresi linier berganda yang diperoleh merupakan hasil perhitungan dengan bantuan program komputer SPSS 20.0. Hasil analisis regresi linear berganda dapat dilihat pada table 4. di bawah ini :

Tabel 4. Hasil Uji t Analisis Regresi Linear Berganda

\begin{tabular}{|c|c|c|c|c|c|c|}
\hline \multicolumn{7}{|c|}{ Coefficients $^{a}$} \\
\hline & & \multicolumn{2}{|c|}{$\begin{array}{l}\text { Unstandardized } \\
\text { Coefficients }\end{array}$} & \multirow{2}{*}{$\begin{array}{c}\text { Standardized } \\
\text { Coefficients } \\
\text { Beta }\end{array}$} & \multirow[b]{2}{*}{$\mathrm{t}$} & \multirow[b]{2}{*}{ Sig. } \\
\hline \multicolumn{2}{|c|}{ Model } & $\mathrm{B}$ & Std. Error & & & \\
\hline 1 & (Constant) &, 214 & ,294 & & ,729 &, 469 \\
\hline & $\times 1$ & , 281 & , 082 & , 303 & 3,444 &, 001 \\
\hline & $\times 2$ & , 361 & , 110 & , 330 & 3,288 &, 002 \\
\hline & $\times 3$ & ,325 & , 092 & , 361 & 3,544 &, 001 \\
\hline
\end{tabular}

Sumber : Data primer diolah, 2021

Berdasarkan hasil perhitungan regresi linier berganda diatas, maka dihasilkan persamaan regresi sebagai berikut :

$$
Y=0,214+0,281 \cdot X_{1}+0,361 \cdot X_{2}+0,325 \cdot X_{3}
$$

Variabel budaya organisasi, kemampuan kerja dan komitmen organisasi memiliki koefisien positif artinya semakin tinggi budaya kerja, kemampuan kerja, dan komitmen organisasi maka semakin tinggi pula kinerja pegawai dan sebaliknya semakin rendah budaya organisasi, kemampuan kerja dan komitmen organisasi maka semakin rendah pula kinerja pegawainya.

\section{a. Uji Hipotes Pertama}

Uji t digunakan untuk menguji pengaruh budaya kerja berpengaruh positif dan signifikan pada kinerja pegawai. Berdasarkan tabel 4.14 dapat diketahui bahwa nilai $\mathrm{t}$ hitung untuk variabel budaya kerja sebesar 3,444. Nilai $t_{\text {tabel }}$ untuk $\mathrm{n}=60, \mathrm{df}=58$ dan $\alpha=5 \%$ adalah 2,002. Nilai $\mathrm{t}$ hitung $>\mathrm{t}$ tabel dan nilai probabilitas $(0,001)$ lebih kecil dari taraf signifikansi 0,05 sehingga Ho ditolak artinya budaya kerja berpengaruh positif dan signifikan pada kinerja pegawai. Hipotesis 1 "Terdapat pengaruh positif budaya kerja terhadap kinerja pegawai" dapat diterima.

\section{b. Uji Hipotes Kedua}

Uji t digunakan untuk menguji pengaruh kemampuan kerja berpengaruh positif dan signifikan pada kinerja pegawai. Berdasarkan tabel 4.14 dapat diketahui bahwa nilai $t_{\text {hitung }}$ untuk variabel kemampuan kerja sebesar 3,288. Nilai $\mathrm{t}_{\text {tabel }}$ untuk $\mathrm{n}=60 \mathrm{df}=58$ dan $\alpha=5 \%$ adalah 2,002. Nilai $t_{\text {hitung }}>t_{\text {tabel }}$ dan nilai probabilitas $(0,002)$ lebih kecil dari taraf signifikansi 0,05 sehingga Ho ditolak artinya kemampuan kerja berpengaruh positif dan signifikan pada kinerja pegawai. Hipotesis 2"Terdapat pengaruh positif kemampuan kerja terhadap kinerja pegawai" dapat diterima.

\section{c. Uji Hipotes Ketiga}

Uji t digunakan untuk menguji pengaruh komitmen organisasi berpengaruh positif dan signifikan pada kinerja pegawai. Berdasarkan tabel 4.14 dapat diketahui bahwa nilai $\mathrm{t}$ hitung untuk variabel kemampuan kerja sebesar 3,544. Nilai $t_{\text {tabel }}$ untuk $n=60, d f=58$ dan $\alpha=5 \%$ adalah 2,002. Nilai $t_{\text {hitung }}>t_{\text {tabel }}$ dan nilai probabilitas $(0,001)$ lebih kecil dari taraf signifikansi 0,05 sehingga Ho ditolak artinya komitmen organisasi berpengaruh positif dan signifikan pada kinerja pegawai. Hipotesis 3 "Terdapat pengaruh positif komitmen organisasi terhadap kinerja pegawai" dapat diterima.

\section{d. Uji Hipotes Keempat}

Uji F digunakan untuk menguji pengaruh budaya kerja, kemampuan kerja, dan komitmen organisasi kerja terhadap kinerja pegawai. Hasil Uji F dapat dilihat pada tabel berikut ini. 
Tabel 5. Hasil Uji F Analisis Regresi Linear Berganda

ANOVA

\begin{tabular}{|ll|r|r|r|r|c|}
\hline Model & & \multicolumn{1}{|c|}{$\begin{array}{c}\text { Sum of } \\
\text { Squares }\end{array}$} & df & Mean Square & F & Sig. \\
\hline 1 & Regression & 23,282 & 3 & 7,761 & 43,680 &, $000^{\mathrm{a}}$ \\
& Residual & 9,949 & 56 &, 178 & & \\
& Total & 33,231 & 59 & & & \\
\hline
\end{tabular}

a. Predictors: (Constant), X3, X1, X2

b. Dependent Variable: $Y$

Sumber : Data primer diolah, 2021

Berdasarkan tabel 5. dapat diketahui bahwa nilai $F_{\text {hitung }}$ sebesar 43,680. Nilai $F_{\text {tabel }}$ untuk $n=60$, $\mathrm{df}_{1}=3, \mathrm{df}_{2}=57$ dan $\alpha=5 \%$ adalah 2,772 . Nilai $\mathrm{F}_{\text {hitung }}>\mathrm{F}_{\text {tabel }}$ dan nilai probabilitas $(0,000)$ lebih kecil dari taraf signifikansi 0,05 , sehingga hipotesis 4 "Terdapat pengaruh signifikan budaya kerja, kemampuan kerja dan komitmen organisasi secara bersama-sama terhadap kinerja pegawai" dapat diterima.

e. Koefisien Determinasi

Koefisien Determinasi ( $R$ Square) merupakan perangkat yang mengukur seberapa jauh kemampuan model dalam menerangkan variasi variabel terikat.

1) Jika nilai koefisien Determinasi ( $R$ Square) mendekati nilai nol, berarti kemampuan variabel-variabel independen dalam menjelaskan variasi variabel dependen sangat terbatas.

2) Jika nilai koefisien Determinasi ( $R$ Square) mendekati satu, berarti variabel-variabel independen memberikan hampir semua informasi yang dibutuhkan untuk memprediksi variasi variabel terikat.

Tabel 6. Koefisien Determinasi ( $R$ Square)

Model Summary

\begin{tabular}{|l|r|r|r|r|}
\hline Model & $\mathrm{R}$ & R Square & $\begin{array}{c}\text { Adjusted } \\
\text { R Square }\end{array}$ & $\begin{array}{r}\text { Std. Error of } \\
\text { the Estimate }\end{array}$ \\
\hline 1 &, $837^{\mathrm{a}}$ &, 701 &, 685 &, 42151 \\
\hline
\end{tabular}

a. Predictors: (Constant), X3, X1, X2

Sumber: Data diolah tahun 2021

Berdasarkan Tabel 6. nilai $R$ Square sebesar 0,701 artinya bahwa 70,1\% variabel kinerja pegawai dapat dijelaskan oleh variabel independen (budaya kerja, kemampuan kerja dan komitmen organisasi). Sedangkan sisanya 29,9\% dijelaskan oleh variabel-variabel lain yang tidak termasuk dalam penelitian ini.

\section{PEMBAHASAN}

\section{Pengaruh Budaya Kerja Terhadap Kinerja Pegawai Menjelang Masa Purnabakti}

Hasil penelitian menunjukkan bahwa budaya kerja mempunyai pengaruh terhadap kinerja pegawai menjelang masa purnabakti. Hasil ini didukung analisi regresi dengan nilai $t_{\text {hitung }}(3,444)>t_{\text {tabel }}$ $(2,002)$ dan nilai probabilitas $(0,001)$ lebih kecil dari taraf signifikansi 0,05 sehingga Ho ditolak artinya budaya kerja berpengaruh positif dan signifikan pada kinerja pegawai. Apabila budaya kerja ditingkatkan maka kinerja pegawai juga akan semakin tinggi, begitu pula sebaliknya jika budaya kerja semakin menurun maka kinerja pegawai juga akan semakin rendah. Hasil penelitian ini sejalan dengan Hasdiah, dkk (2018) membuktikan bahwa budaya kerja juga berpengaruh signifikan terhadap kinerja pegawai. Susanto (2000) menjelaskan, dalam mengurai permasalahan dari luar serta menyesuaikan integrasi dengan perusahaan sumber daya manusia membutuhkan suatu pedoman, hingga setiap anggota 
organisasi dapat mengenal nilai-nilai serta perilaku yang seharusnya mereka perlihatkan, nilai tersebut dikenal sebagai budaya kerja.

\section{Pengaruh Kemampuan Kerja Terhadap Kinerja Pegawai Menjelang Masa Purnabakti}

Hasil penelitian menunjukkan bahwa kemampuan kerja mempunyai pengaruh terhadap kinerja pegawai menjelang masa purnabakti. Hasil ini didukung analisi regresi dengan nilai $t_{\text {hitung }}(3,288)>t_{\text {tabel }}$ $(2,002)$ dan nilai probabilitas $(0,002)$ lebih kecil dari taraf signifikansi 0,05 sehingga Ho ditolak artinya kemampuan kerja berpengaruh positif dan signifikan pada kinerja pegawai. Apabila kemampuan kerja ditingkatkan maka kinerja pegawai juga akan semakin tinggi, begitu pula sebaliknya jika kemampuan kerja semakin menurun maka kinerja pegawai juga akan semakin rendah. Hasil penelitian ini sejalan dengan Jatiningrum, dkk (2016) membuktikan bahwa kemampuan kerja berpengaruh terhadap kinerja karyawan. Kemampuan kerja merupakan kapasitas individu untuk melakukan beragam tugas dalam suatu pekerjaan. Kemampuan mencerminkan sebuah penilaian terkini atas apa yang dapat dilakukan seseorang.

\section{Pengaruh Komitmen Organisasi Terhadap Kinerja Pegawai Menjelang Masa Purnabakti}

Hasil penelitian menunjukkan bahwa komitmen organisasi mempunyai pengaruh terhadap kinerja pegawai menjelang masa purnabakti. Hasil ini didukung analisi regresi dengan nilai $t_{\text {hitung }}$ $(3,544)>t_{\text {tabel }}(2,002)$ dan nilai probabilitas $(0,001)$ lebih kecil dari taraf signifikansi 0,05 sehingga Ho ditolak artinya komitmen organisasi berpengaruh positif dan signifikan pada kinerja pegawai. Apabila komitmen organisasi ditingkatkan maka kinerja pegawai juga akan semakin tinggi, begitu pula sebaliknya jika komitmen organisasi semakin menurun maka kinerja pegawai juga akan semakin rendah. Hasil penelitian ini sejalan dengan Muis, dkk, (2018) membuktikan bahwa ada pengaruh positif dan signifikan komitmen organisasi terhadap kinerja karyawan. Kondisi seorang pegawai yang mengerahkan untuk berpihak pada organisasi serta tujuannya, juga menjaga keanggotaanya, dinamakan komitmen organisasi. Tingginya individu saat terlibat menandakan keterpihakannya pada pekerjaan, sedang tingginya komitmen organisasi menandakan keberpihakan pada organisasi yang memberi individu sebuah pekerjaan.

\section{Pengaruh Budaya Kerja, Kemampuan Kerja Dan Komitmen Organisasi Terhadap Kinerja Pegawai Menjelang Masa Purnabakti}

Hasil penelitian menunjukkan bahwa budaya kerja, kemampuan kerja, dan komitmen organisasi mempunyai pengaruh terhadap kinerja pegawai menjelang masa purnabakti. Hasil ini didukung analisi regresi dengan nilai $\mathrm{F}_{\text {hitung }}(43,680)>\mathrm{F}_{\text {tabel }}(2,772)$ dan nilai probabilitas $(0,001)$ lebih kecil dari taraf signifikansi 0,05 sehingga Ho ditolak, artinya budaya kerja, kemampuan kerja, dan komitmen organisasi berpengaruh positif dan signifikan pada kinerja pegawai. Apabila budaya kerja, kemampuan kerja, dan komitmen organisasi ditingkatkan maka kinerja pegawai juga akan semakin tinggi, begitu pula sebaliknya jika budaya kerja, kemampuan kerja, dan komitmen organisasi semakin menurun maka kinerja pegawai juga akan semakin rendah. Nilai $R$ Square sebesar 0,701 artinya bahwa $70,1 \%$ variabel kinerja pegawai dapat dijelaskan oleh variabel independen (budaya kerja, kemampuan kerja dan komitmen organisasi). Sedangkan sisanya $29,9 \%$ dijelaskan oleh variabel-variabel lain yang tidak termasuk dalam penelitian ini.

Dengan demikian temuan penelitian pada kinerja pegawai ketika memasuki masa purnabakti ternyata masih memiliki kinerja yang dibaik karena ditunjang dengan budaya kerja yang masih disiplin dan kekeluargaan, kemampuan kerja yang mereka pegawai masih mau belajar untuk menyesuaikan kemampuan kerja mereka dengan perubahan teknologi informasi akibat pandemi serta komitmen instansi dalam melakukan berbagai pelatihan dan pemberian penghargaan terhadap pengabdian para pegawai.

\section{KESIMPULAN} berikut:

Berdasarkan hasil analisis yang telah dibahas sebelumnya, dapat ditarik kesimpulan sebagai

1. Budaya kerja berpengaruh positif dan signifikan pada kinerja pegawai menjelang masa purnabakti pada lingkup Kanwil Direktorat Jenderal Perbendaharaan Provinsi D. I. Yogyakarta.

2. Kemampuan kerja berpengaruh positif dan signifikan pada kinerja pegawai menjelang masa purnabakti pada lingkup Kanwil Direktorat Jenderal Perbendaharaan Provinsi D. I. Yogyakarta. 
3. Komitmen organisasi berpengaruh positif dan signifikan pada kinerja pegawai menjelang masa purnabakti pada lingkup Kanwil Direktorat Jenderal Perbendaharaan Provinsi D. I. Yogyakarta.

4. Budaya kerja, kemampuan kerja, dan komitmen organisasi berpengaruh positif dan signifikan secara bersama-sama pada kinerja pegawai menjelang masa purnabakti pada lingkup Kanwil Direktorat Jenderal Perbendaharaan Provinsi D. I. Yogyakarta.

\section{SARAN}

1. Saran Praktis dalam Penelitian ini yaitu agar Pimpinan di Kanwil Ditjen Perbendaharaan Provinsi D. I. Yogyakarta dapat meningkatkan kinerja pegawai melalui peningkatan kemampuan kerja dengan mengadakan diklat untuk menggunakan teknologi berbasis Teknologi Informasi baik secara daring maupun tatap muka sehingga pegawai yang memasuki masa purna bakti tetap dapat bekerja dengan produktif dan bagi Pegawai di Kanwil Direktorat Jenderal Perbendaharaan Provinsi D. I. Yogyakarta supaya dapat meningkatkan kinerjanya dengan bekerja yang secara profesional meskipun bekerja di rumah.

2. Saran Teoritis dalam penelitian ini yaitu hasil penelitian ini dapat dijadikan referensi untuk penelitian berikutnya dengan menambahkan faktor-faktor lain yang mempengaruhi kinerja pegawai seperti kompetensi, kompensasi, kepuasan kerja dan lain sebagainya.

\section{REFERENSI}

As'ad, Moh. 2001, Psikologi Industri, Edisi Keempat, Cetakan Kelima, Liberty, Yogyakarta.

Dessler, Gary, 2010. Manajemen Sumber Daya Manusia. Jakarta: PT Index Kelompok Gramedia.

Hasibuan, Malayu S.P. 2012. Manajemen SDM. Edisi Revisi, Cetakan Ke Tigabelas. Jakarta: Bumi Aksara.

Hasdiah, dkk. 2018. Pengaruh Motivasi dan Budaya Kerja Terhadap Kinerja Pegawai Di Kantor Sekertariat Daerah Kabupaten Enrekang. Medan, 30 November- 03 Desember 2018 APPPTMA $K E-8$, Prosiding Konferensi Nasional Ke- 8 Asosiasi Program Pascasarjana Perguruan Tinggi Muhammadiyah (APPPTMA) ISBN: 978-623-90018-0-3.

Jatiningrum, Citra Dewi. dkk. 2016. Pengaruh Budaya Organisasi, Motivasi dan Kemampuan Terhadap Kinerja (Studi Pada Karyawan dan Agen PT Asuransi Jiwasraya Branch Office Malang). Jurnal Administrasi Bisnis (JAB) Vol. 39 No. 1 Oktober 2016, hal. 117-124.

Mangkunegara, Anwar Prabu. 2005. Evaluasi Kinerja SDM. Cetakan Pertama. PT. Refika Aditama, Bandung.

Mathis, Robert L dan Jhon H. Jackson. 2011. Manajemen Sumber Daya Manusia. Buku II, Penerjemah: Jimmy Sadeli dan Bayu Prawira Hie, Jakarta: Salemba Empat.

Moeljono, Djokosantoso. 2005. Budaya Organisasi dalam Tantangan. Jakarta: PT. Elex Media Komputindo.

Muis, Muhammad Ras. J. Jufrizen dan Muhammad Fahmi. 2018. Pengaruh Budaya Organisasi dan Komitmen Organisasi Terhadap Kinerja Karyawan. Jurnal Ekonomi \& Ekonomi Syariah Vol 1 No 1 Januari 2018 E-ISSN 2599-3410; P-ISSN : 2614-3259.

Nasution, M. I. (2017). Pengaruh Stres Kerja, Kepuasan Kerja Dan Komitmen Organisasi Terhadap Turnover Intention Medical Representative. MIX: Jurnal Ilmiah Manajemen. 7(3), 407-428.

Putranti, Honorata Ratnawati Dwi. Megawati, dan Setyobudi, 2018, Pengaruh Budaya Kerja Dan Komitmen Organisasi Terhadap Kinerja Melalui Motode TULTA Sebagai Variabel Kontrol, Jurnal Inspirasi Bisnis dan Manajemen, Vol 2, (2), 2018, 191-201 e-2579-9401, p-2579-9312.

Rao T, V. 2000. Penilaian Prestasi Kerja: Teori dan Praktek. Jakarta: Pustaka Binaman Pressindo. 
Robbins, Stephen P. 2006. Perilaku Organisasi, Konsep, Kontroversi, Aplikasi, Penterjemah: Handyana Pujaatmaka. Jakarta: PT. Prenhallindo.

Robbins, Stephen P. dan Timothy A. Judge. 2008. Perilaku Organisasi Edisi ke-12, Jakarta: Salemba Empat.

Silvia, I Wayan Bagia, dan Wayan Cipta. 2016. Pengaruh Kompetensi dan Budaya Kerja terhadap Kinerja Karyawan. e-Journal Bisma Universitas Pendidikan Ganesha Jurusan Manajemen (Volume 4 Tahun 2016), hal. 1-10.

Susanto, A . B. 2000. Budaya Perusahaan: Manajemen dan Persaingan Bisnis. Jakarta: PT Gramedia.

Sunjaya, Oky Pratama Adi. dkk. 2017, Pengaruh Budaya Kerja, Kemampuan dan Komitmen Organisasi terhadap Kinerja Karyawan Bagian Produksi pada PT. PhaprosTbk Semarang. Journal of Management. ISSN : 2502-7689 Vol 3, No 3 (2017), hal. 1-7.

Thoha, Miftah. 2002. Perilaku Organisasi Konsep Dasar dan Aplikasinya. Jakarta: PT. Raja Grafindo Persada.

Wirawan, 2009, Evaluasi Kinerja Manajemn Sumberd Daya Manusia, Jakarta: Salemba Empat.

Yudho Winarto, 2020, Pemerintah izinkan PNS kerja di rumah karena corona, ini detail isi edarannya, diakses dari https://nasional.kontan.co.id/news/pemerintah-izinkan-pns-kerja-di-rumahkarena-corona-ini-detail-isi-edarannya. 